\title{
New Technique: Paravertebral Muscle Refashioning in Meningiomyelocele Repair
}

\author{
MOHAMED M. EL-MAGHRABI, M.D.; MOATAZ A ELAWADY, M.D. and AHMED A. ARAB, M.D. \\ The Department of Neurosurgery, Faculty of Medicine, Benha University, Benta, Egypt
}

\begin{abstract}
Background: One of the most complications of meningiomyelocele surgical repair is early postoperative Cerebrospinal fluid (CSF) leakage. Cystic back swelling due to prolonged sitting of children is an annoying symptom of their parents.

Aim of the Study: To assess the technique of paravertebral muscle refashioning in meningiomyelocele repair as a protective layer of opened spinal canal.

Study Design: A prospective clinical trial study of 46 infants, 25 boys and 21 girls, with meningiomyelocele which was repaired surgically using paravertebral muscle refashioning technique in 18 infants (group I) while 28 infants without this technique (group II) at Benha University and Benha children Hospitals through the period from May 2013 to April 2017. The mean period of follow-up was (18.27 \pm 2.78 months).
\end{abstract}

Patients and Methods: Comparison was performed between two groups by analysis of early postoperative CSF subcutaneous swelling and late pulsatile cystic swelling of repaired defect.

Results: Forty six infants were studied, 25 boys ( $54.3 \%)$ and 21 girls $(45.7 \%)$ with mean age $29.7 \pm 15.39$ days (ranging from 1 to 90 days), and they were followed up with a mean of $18.27 \pm 2.78$ months (ranging from 12 to 24 months). Early postoperative CSF leakage was absent in $72.8 \%$ of group I and $71.4 \%$ of group II which was statistically non significant between two techniques while late cystic back swelling was not detected in $88.9 \%$ of group I and only $32.1 \%$ of group II which was statistically significant $(p<0.001)$.

Conclusion: Paravertebral muscle refashioning in meningiomyelocele repair is an effective technique for prevention of late cystic back swelling.

Key Words: Paravertebral muscle refashioning - Meningiomyelocele repair.

\section{Introduction}

THE major indication for operative repair of meningomyeloceles is prevention of infection, as

Correspondence to: Dr. Mohamed M. El-Maghrabi, The Department of Neurosurgery, Faculty of Medicine, Benha University, Benta, Egypt the open neural tube is continuous with the exterior, and those infants are at risk for bacterial meningitis due to the spinal defect. One of the most complications of meningiomyeloceles surgical repair is early postoperative CSF leakage $[\mathbf{1}, 2]$. Cystic back swelling due to prolonged sitting of children is an annoying symptom of their parents $[3,4]$.

We aim to assess the technique of paravertebral muscle refashioning in meningomyeloceles repair as a protective layer of opened spinal canal.

\section{Patients and Methods}

Study design: A prospective clinical trial study of 46 infants were included, a mean age with meningiomyelocele (or myelocele) with spine defect area was $\geq 20 \mathrm{~cm}$ which was repaired surgically using paravertebral muscle refashioning technique in 18 infants (group I) while 28 infants without this technique (group II) at Benha University and Benha Children Hospitals through the period from May 2013 to April 2017.

Methods: Comparison was performed between two groups by analysis of early postoperative CSF subcutaneous swelling and late pulsatile cystic swelling of repaired defect.

Patient population: There were 25 boys and 21 girls involved in this study with a mean age of $29.7 \pm 15.39$ days (range 1 to 90 days).

Preoperative work-up: All patients underwent routine history and neurological examination with Magnetic Resonance Imaging (MRI) \pm Computerized Tomography (CT) to complete radiological

\footnotetext{
Abbreviation:

CSF : Cerebrospinal Fluid.

CT : Computerized Tomography.

MRI : Magnetic Resonance Imaging.
} 
assessment of the defect area of the spine. The measurement of spine defect area was calculated clinically for all patients using graduated tap, defect area $\left(\mathrm{cm}^{2}\right)=$ Length $(\mathrm{cm}) \times$ width $(\mathrm{cm})$. Paravertebral muscle refashioning was not planed preoperative.

Operative note: All patients included in this study had meningiomyelocele (or myelocele) with spinal defect area $\geq 20 \mathrm{~cm}$. A new surgical technique in group I was done after reconstruction and water tight closure of the dura Fig. (1a). Longitudinal incisions, one on each side parallel to the spinal column, was used for cutting lumbar sheath and paravertebral muscle with scalpel (no. 15) to about a half of muscle thickness then splitting the muscle medially without tearing the splitted layer nor disconnection from its bony attachment medially (Fig. 1b-d), hemostasis for any bleeding points during muscle splitting using bipolar. Each muscle flap was turned medially on spine defect covering it with simple sutures were applied to adequate closure of muscle layer as in Fig. (1e,f) and protecting the repaired dura. In three cases defect covering was done up to $85 \%$ with inability to cover the distal part due to under development of paravertebral muscles distally. Reconstruction and closure of skin without external drain was done. In group II, reconstruction and closure of dura and skin without drain were applied only.
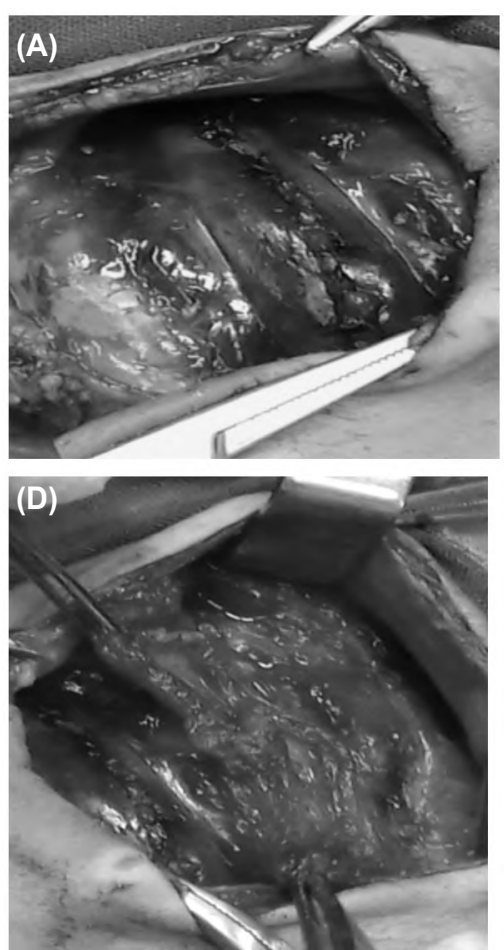
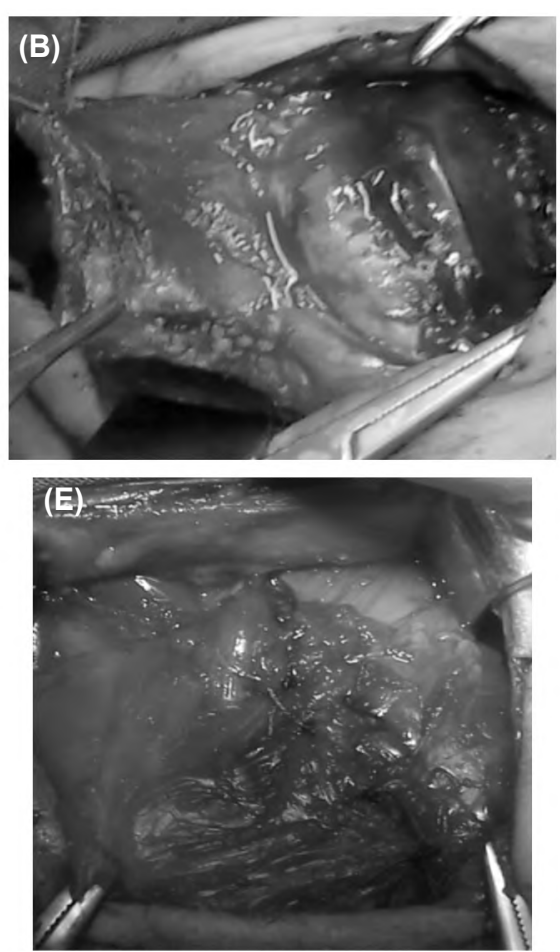
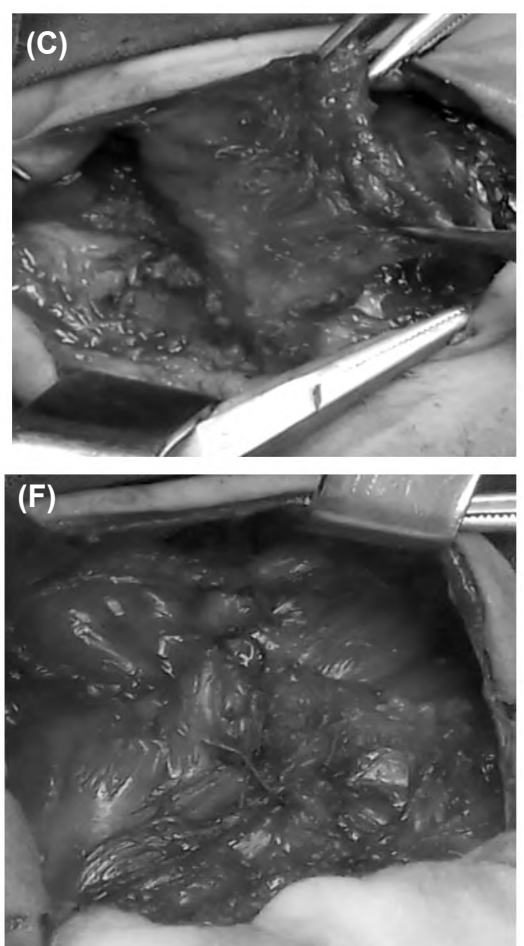

Fig. (1A-F): Technique of paravertebral muscle refashioning in meningiomyelocele surgical repair; (A) Dural reconstruction and water tight closure, (B\&C) Views of Lt splitted muscle flap, (D) View of Rt splitted muscle flap, $(\mathrm{E} \& \mathrm{~F})$ Suturing of both flaps together with complete covering of spinal defect.

Postoperative follow-up: Main two points related to our technique were early subcutaneous swelling due to postoperative CSF leakage and late pulsatile cystic swelling of repaired dura, detection of this cystic swelling was observed by palpation mainly \pm inspection. Patients were followed clinically for a mean period of $18.27 \pm 2.78$ month with range from 12 to 24 months.

\section{Statistical analysis:}

SPSS (Version 20.0 for Windows, SPSS Inc, Chicago, IL) was used for analyzes of the data. Qualitative data were summarized as number and percentages while quantitative data as mean \pm SD.
Student $t$-test was applied for the comparison of quantitative variables while chi square test for qualitative variables. Correlations among variables were studied by using the pearson correlation. A $p$-value $<0.05$ was considered statistically significant $(*)$ while $>0.05$ statistically insignificant.

\section{Results}

Meningiomyelocele repair was done in forty six patients who were classified into group I (with technique of paravertebral muscle refashioning) in eighteens patients (39.1\%) and group II (without refashioning) in twenty eight patients $(60.9 \%)$. 
Table (1) shows those twenty five boys (54.3\%) and twenty one girls (45.7\%), with mean age $29.7 \pm$ 15.39 days and ranging from 1 to 90 days, were included in this study and they were followed-up clinically for a mean period of $18.27 \pm 2.78$ months with range from 12 to 24 months.

In Table (2), early postoperative CSF leakage is absent in thirteen patients $(72.8 \%)$ of group I and twenty patients $(71.4 \%)$ of group II which is statistically non significant between two techniques.

Table (1): Distribution of the studied group.

\begin{tabular}{lc}
\hline Variable & Studied group (46) \\
\hline Age/days: & \\
Mean \pm SD & $29.7 \pm 15.39$ \\
Range & $1-90$ \\
Sex $n(\%):$ & \\
Boys & $25(54.3 \%)$ \\
Girls & $21(45.7 \%)$ \\
Follow-up period /months: & \\
Mean \pm SD & $18.27 \pm 2.78$ \\
Range & $12-24$ \\
\hline
\end{tabular}

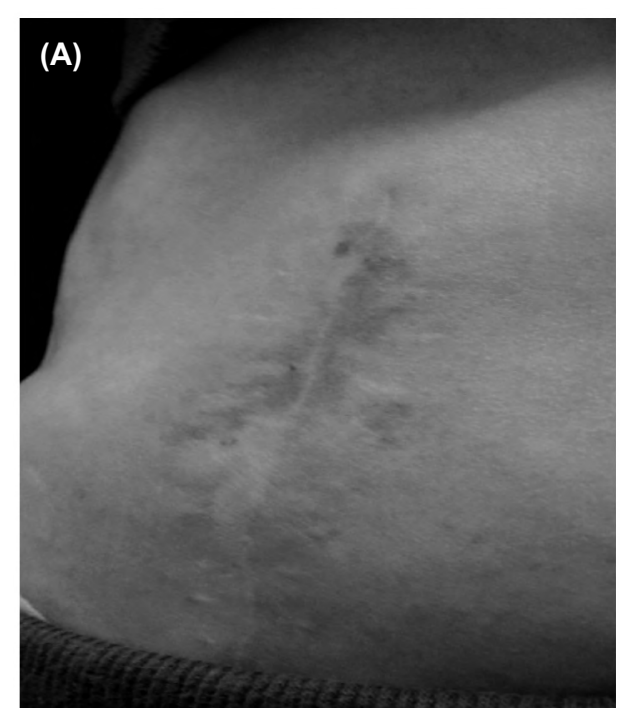

Fig. (1A-F): Late postoperative meningiomyelocele repair follow-up; (A) group I (postop. 14 months), (B) group II (postop. 17 months).

\section{Discussion}

Various methods have been used in the surgical repair of meningomyeloceles. Primary repair with undermining the edges is favored by some surgeons as the main repair $[\mathbf{5 , 6 ]}$. The kind of skin closure performed is determined by the size of the spinal defect. Ozveren et al., [7] used the size of the defect
Late pulsatile cystic back swelling, as in Fig. (2), is not detected in sixteen patients $(88.9 \%)$ of group I but only in nine patients $(32.1 \%)$ of group II which is statistically significant $(p<0.001)$ between two techniques.

Total operative time is $70.04 \pm 5.22$ minutes (range: 60-95) in group I while 67.98 \pm 6.32 minutes (range 51-88) in group II which is statistically non significant between two groups. No serious operative or postoperative complication had occurred.

Table (2): Comparison between two groups postoperatively.

\begin{tabular}{|c|c|c|c|c|}
\hline & $\begin{array}{l}\text { Group } \\
\text { I (18) }\end{array}$ & $\begin{array}{l}\text { Group } \\
\text { I (28) }\end{array}$ & $\begin{array}{c}\text { Statistical } \\
\text { test }\end{array}$ & $\begin{array}{c}p- \\
\text { value }\end{array}$ \\
\hline $\begin{array}{c}\text { Early CSF } \\
\text { eakage: } \\
\text { Present } \\
\text { Absent }\end{array}$ & $\begin{array}{l}5(27.8 \%) \\
13(72.2 \%)\end{array}$ & $\begin{array}{l}8(28.6 \%) \\
20(71.4 \%)\end{array}$ & $\begin{array}{l}X^{2}= \\
0.003\end{array}$ & 0.95 \\
\hline $\begin{array}{l}\text { Late back } \\
\text { swelling: } \\
\text { Present } \\
\text { Absent }\end{array}$ & $\begin{array}{l}2(11.1 \%) \\
16(88.9 \%)\end{array}$ & $\begin{array}{l}19(67.9) \\
9(32.1)\end{array}$ & $\begin{array}{l}\mathrm{X}^{2}= \\
14.22\end{array}$ & $0.001 * *$ \\
\hline $\begin{array}{l}\text { Total operative } \\
\text { time/minutes: } \\
\text { Mean } \pm \mathrm{SD} \\
\text { Range }\end{array}$ & $\begin{array}{l}70.04 \pm 5.22 \\
60-95\end{array}$ & $\begin{array}{l}67.98 \pm 6.32 \\
51-88\end{array}$ & $t=1.2$ & 0.24 \\
\hline
\end{tabular}

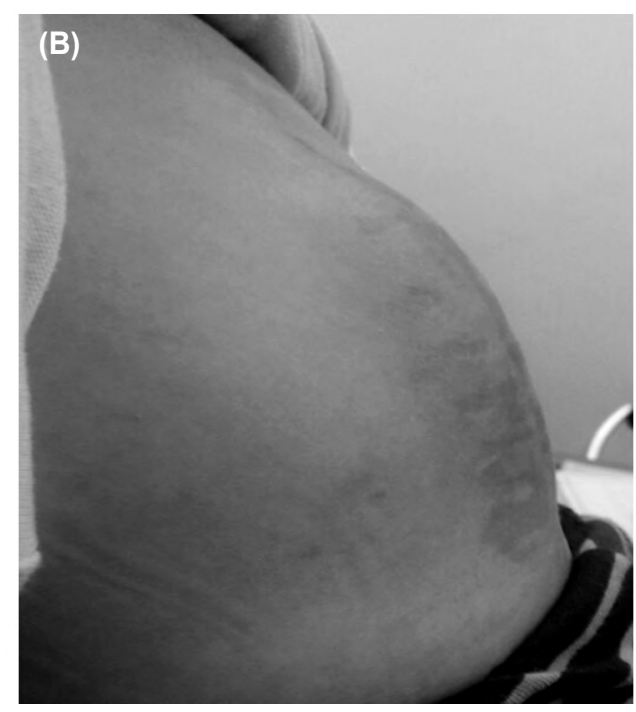

area as a percentage of the thoraco-lumbar region to make it possible to select the closure technique. Any defect smaller than $8 \%$ of the thoraco-lumbar region was classified as grade 1 and can be closed primarily, while those occupying more than $8 \%$ are classified as grade 2 and needs plastic reconstruction. A better and easier method was introduced by de Chalain et al., [8] suggesting that an area of 
spinal deficit larger than 20-25 square centimeters is an indication for plastic surgical reconstruction.

In our study, all patients with spinal defect area $>20 \mathrm{~cm}^{2}$ were without preoperative planning of operation type.

Primary closure of myelomeningioceles has been reported at rates of 75-95\% [6,9]. This primary wound healing is suitable for small myelomeningiocele defects with wide undermining of the wound edges and direct closure of the wound [10]

In our study, all patients was primarily closed externally as regard skin closure without the need for plastic planning, otherwise as regard deep layers, $60.9 \%$ of our patients (group II) had no added work while in $39.1 \%$ (group I) refashioning of paravertebral muscles technique was used.

Several variations of skin flaps have been described to close large myelomeningiocele defects [11]. Advancement flaps, bipedicled flaps, local transposition flaps, bilobed flaps, double Z-plasty, rotation flaps, and Limberg flaps, which can be used successfully in the closure of large myelomeningocele defects. Regardless of the technique used, it should be tension free, provide good softtissue padding of the neural tube, prevent CSF leakage, and provide stable and durable wound healing, especially for large defects. Additionally, the techniques used to reconstruct the defect should result in less morbidity [10,12]. McDevitt et al., and Moore et al., [13,14] suggested closure of thoracolumbar and lumbaosacral defects with bilateral bipedicle flaps consisting of latissimus dorsi myocutaneous and extended gluteal fasciocutaneous units. Ramirez et al., [15] described the technique of en bloc medial advancement of the combined interconnected latissimus dorsi and gluteus maximus myocutaneous units without lateral relaxing incisions. Ramasastry and Cohen [16] studied this technique and stated that it provides a tension free, durable and viable soft tissue coverage over the dural repair [17]. In 2001, Lapid et al., [18] advocated the use of bilobed flap in the surgical repair of meningiomyelocele.

Early postoperative CSF leakage is considered one of the most early complications of meningiomyeloceles surgery that was absent in $81.34 \%$ in all types of repair [2] while in our study, it was absent in $72.8 \%$ and $71.4 \%$ of group I and II respectively.

Cystic pulsatile back swelling due to prolonged sitting of children is an annoying symptom of their parents [3.4] with no calculation of its percent in literature. While, in our study, cystic pulsatile back swelling is not detected in $88.9 \%$ and $32.1 \%$ of group I and II respectively, which is statistically significant between that groups.

The use of myocutaneous flaps have also been tried despite increasing the operative and anesthesia time $[6,19]$

Our technique has been used in 18 patients. We encountered no major complications related to the surgery. There was no flap loss, necrosis or wound dehiscence, and early CSF leaks in 5 patients subsided rapidly in less than 6 days. The extratime added to the total operative time needed in this technique was not so long as compared between the two groups which is statistically non significant and had resulted in no anesthetic complications such as hypothermia or blood loss.

\section{Conclusion:}

Paravertebral muscle refashioning in meningiomyelocele repair is an effective technique for prevention of late cystic back swelling without significant increase of total operative time.

\section{Acknowledgment:}

The authors thank all parents of included patients.

Funding:

This study had no funding from any resource.

\section{Competing interests:}

The authors declare that they have no conflict of interest.

\section{Ethical approval:}

This research accepted by Research Ethics Committee (REC) of faculty of medicine, Benha University (chairman: Prof/ Ibrahim El-Gendy).

All procedures performed in studies involving human participants were in accordance with the ethical standards of the institutional and/or national research committee and with the 1964 Helsinki declaration and its later amendments or comparable ethical standards. A written informed consent was obtained from parents of patients after explaining all steps of this study.

\section{Authors' contributions}

Mohamed Elmaghrabi performed the operative and clinical parts of the study.

Mohamed Elmaghrabi, Moataz Elawady and Ahmed Arab analyzed the data and wrote the paper with revision carefully of the final version of the manuscript. 


\section{References}

1- CHAND M.B., AGRAWAL J. and BISTA P.: Anaesthetic Challenges and Management of Myelomeningocele Repair. Postgraduate Medical Journal of NAMS, 11 (1), 2011.

2- DUFFY F.J., WEPRIN B.E. and SWIFT D.M.: A new approach to closure of large lumbosacral myelomeningoceles: The superior gluteal artery perforator flap. Plast. Reconstr. Surg., 114: 1864-1868, 2004.

3- ADZICK N.S.: Fetal myelomeningocele: Natural history, pathophysiology, and in-utero intervention. Semin. Fetal. Neonatal. Med., 15: 9-14, 2010.

4- ADZICK N.S.: Fetal surgery for spina bifida: Past, Present, Future. Semin. Pediatr. Surg., 22: 10-7, 2013.

5- MUSKETT A., BARBER W.H. and PARENT A.D.: Contemporary postnatal plastic surgical management of meningomyelocele. J. Plast. Reconstr. Aesthet. Surg., 65: 572577.

6- NEJAT F., BARADARAN N. and EL KHASHAB M. Large myelomeningocele repair. Indian Journal of Plastic Surgery, 44 (1): 87-90, 2011.

7- OZVEREN M.F., EROL F.S., TIFTIKCI M.T. and AKDEMIR I.: The significance of the defect size in spina bifida cystica in determination of the surgical technique. Childs Nerv. Syst., 18: 614, 2002.

8- De CHALAIN T.M., COHEN S.R. and BURSTEIN F.D. Decision making in primary surgical repair of myelomeningocele. Ann. Plast. Surg., 35: 272-278, 1995.

9- SHIM J.H., HWANG N.H., YOON E.S., DHONG E.S., KIM D.W. and KIM S.D.: Closure of Myelomeningocele Defects Using a Limberg Flap or Direct Repair. Arch. Plast. Surg., 43: 26-31, 2016.

10- GHOZLAN N.A. and EISA A.M.: Reconstruction of Broad-Based Myelomeningocele Defects: A Modified Technique. Eg. J. Plast. Reconstr. Surg., 31 (2): 213-219, 2007.
11- EL-SABBAGH A.H. and ZIDAN A.S.: Closure of large myelomeningocele by lumbar artery perforator flaps. J. Reconstr. Microsurg., 27: 287-294, 2011.

12- KEMALO GLU C.A., ÖZYAZGAN I. and ÜNVERDI Ö.F.: A decision-making guide for the closure of myelomeningocele skin defects with or without primary repair. J. Neurosurg. Pediatr., 18: 187-193, 2016.

13- Mc DEVITT N.B., GILLESPIE R.D., WOOLSEY R.E., WHITT J.J. and BEVIN A.G.: Closure of thoracic and lumbar dysraphic defects using bilateral latissimus dorsi myocutaneous flap transfer with extended gluteal fasciocutaneous flaps. Child's Brain., 9: 394-398, 1982.

14- MOORE T.S., DREYER T.M. and BEVIN A.G.: Closure of large spina bifida cystica defects with bilateral bipedicled musculocutaneous flaps. Plast. Reconstr. Surg., 73: 288-292, 1984.

15- RAMIREZ O.M., RAMASASTRY S.S., GRANICK M.S., PANG D. and FUTRELL J.W.: A new surgical approach to closure of large lumbosacral meningomyelocele defects. Plast. Reconstr. Surg., 80: 799-807, 1987.

16- SARIFAKIOGLU N., BINGÜL F., TERZIOGLU A., ATES L. and ASLAN G.: Bilateral split latissimus dorsi $\mathrm{V}$-Y flaps for closure of large thoracolumbar meningomyelocele defects. Br. J. Plast. Surg., 56: 303-306, 2003.

17- RAMASASTRY S.S. and COHEN M.: Soft tissue closure and plastic surgical aspects of large open myelomeningoceles. In Pang D. (Ed): Neurosurgery Clinics of North America, Spinal Dysraphism. Philadelphia: WB Saunders Pub., 279-291, 1995.

18- LAPID O., ROSENBERG L. and COHEN A.: Meningomyelocele reconstruction with bilobed flaps. British Journal of Plastic Surgery., 54: 570-572, 2001.

19- PATEL K.B., TAGHINIA A.H. and PROCTOR M.R.: Extradural myelomeningocele reconstruction using local turnover fascial flaps and midline linear skin closure. J. Plast. Reconstr. Aesthet. Surg., 65: 1569-1572, 2012. 


\section{طريقة جديلة اعادة تشكيل العضلات الجار فقارية فى اصلاح

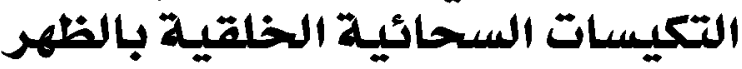

الخفية: من اهـم المشاكل جراحة اصلاح التكيس السحائى الخلقى بالظهر هو تسرب السائل النخاعى المبكر كما يعتبر التومر

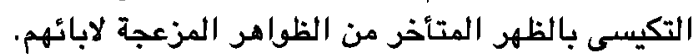

الهدف: تهدف الدراسة لتقييم طريقة اعادة تشكيل العضلات الجارفقارية فى اصلاح التكيسات السحائية الخلقية بالظهر كطبقة حامية للخلل بالقناة العصبية.

تصميم الدراسة: هذه الدراسة اكلينيكية مستقبلية على 7ع رضيع والذين اجريت لهم جراحة اعادة تثكيل العضلات الجار فقارية

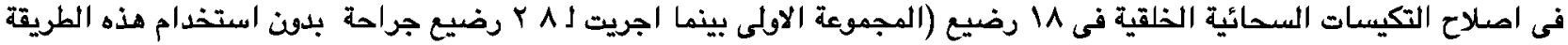

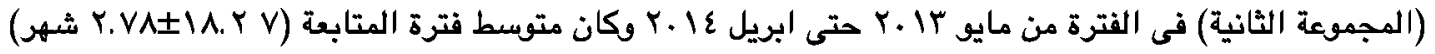

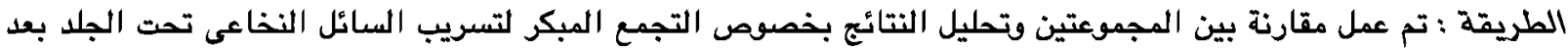

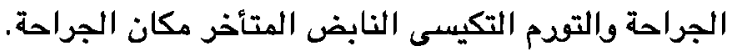

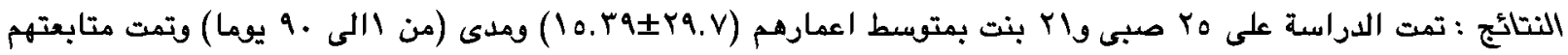

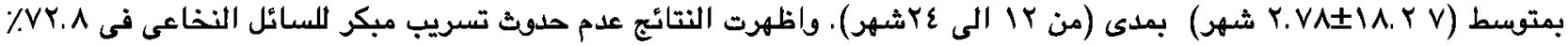

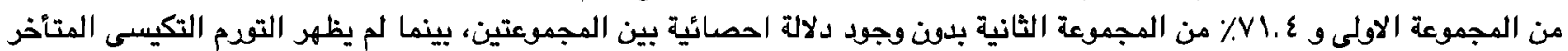

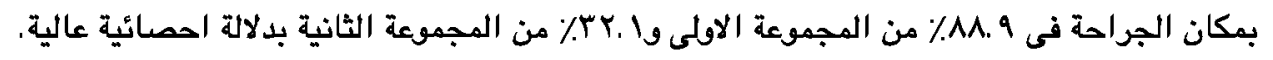

الخلاصة : تعتبر اعادة تثكيل العضلات الجارفقارية في اصلاح التكيسات السحائية الخلقية بالظهر طريقة فعالة في منع التوم التكيسى المتأخر بمكان الجراحة. 